\title{
Covid-19, Environmental Engineering and the End of the World as We Know it
}

\author{
Koronawirus, inżynieria środowiska \\ i koniec świata, jaki znamy
}

\author{
Artur Pawłowski \\ Lublin University of Technology, Faculty of Environmental Engineering, \\ ul. Nadbystrzycka 40B, 20-618 Lublin, Poland \\ E-mail: a.pawlowski@pollub.pl, Researcher ID: C-2649-2017, \\ ORCID: 0000-0002-8764-1534, Scopus Author ID: 24076801000
}

\begin{abstract}
Covid-19 stopped the World. When all humanity is worried about their health, is there still any room for technical sciences and environmental engineering? In this work, It will be proved, that the answer is yes. Major challenges, such as climate change, are still valid. In addition, being in a quarantine still we have access to clean water and electricity. Without these goods, our lives in these conditions would be much harder. Investments in renewable energy sources are still being carried out.

Covid-19 will not bring the end of the World as such, but the end of the World as we know it. Some sectors of the economy (tourism, public transport, in particular air transport) may cease to exist and the service sector will face a deep recession. This means a gigantic economic crisis and retraction of the World development many years back.
\end{abstract}

Key words: coronavirus, Covid-19, epidemic, environmental engineering, global crisis

\section{Streszczenie}

Koronawirus zatrzymał świat. Gdy wszyscy martwią się o swoje zdrowie, czy jest tu jeszcze miejsce dla nauk technicznych i inżynierii środowiska? W tej pracy udowadniam, że tak. Główne wyzwania, takie jak zmiany klimatyczne, są nadal aktualne. Poza tym przebywając na kwarantannie cały czas mamy dostęp do czystej wody i energii elektrycznej. Bez tych dóbr nasze życie w tych warunkach byłoby trudniejsze. Inwestycje w odnawialne źródła energii także nie uległy zatrzymaniu.

Covid-19 nie przyniesie ze sobą końca świata jako takiego, ale nastąpi koniec świata, jaki znamy. Niektóre sektory gospodarki (turystyka, transport publiczny, w szczególności lotniczy) mogą przestać istnieć, a sektor usług czeka głęboka recesja. Oznacza to gigantyczny kryzys ekonomiczny i cofnięcie rozwoju świata o wiele lat.

Słowa kluczowe: koronawirus, inżynieria środowiska, kryzys globalny

\section{Introduction}

Covid-19 (coronavirus disease of 2019) stopped the World, as for the last few months millions of people were staying at home in a quarantine. In such conditions, when looking for a vaccine is a priority, it would seem that technical sciences, like environmental engineering, are becoming less important. It will be proved that technology still matters, however first let's deal with changes that epidemics bring to our life.

\section{Epidemics in history}

Epidemic is nothing new, 10 biggest such cases in the history are presented in table 1 .

One of the biggest epidemic in history was Black Death, which took about 200 million lives. The World Population were at that time at the level of around 450 million people. So, the plague took $45 \%$ of the entire human race! After The Black Death it took 200 years to rebuild the population again (MPH, 2020). 
Table 1. Epidemics in history (from more recent to the oldest), source: MPH, 2020, changed

\begin{tabular}{|c|c|c|c|c|}
\hline No & Name & Date & Death tool & Comment \\
\hline 1 & Covid-19 & 2019-? & $\begin{array}{l}\text { Unknown, } \\
346000 \text { as for } \\
\text { the May } 2020\end{array}$ & $\begin{array}{l}\text { Cause: virus. } \\
\text { It begun in China around December 2019, then } \\
\text { spread around the globe. }\end{array}$ \\
\hline 2 & AIDS Pandemic & 1976-? & $\begin{array}{l}32 \text { million so } \\
\text { far }\end{array}$ & $\begin{array}{l}\text { Cause: HIV virus. } \\
\text { It was identified in } 1976 \text { in Democratic Re- } \\
\text { public of the Congo. Then it has become } \\
\text { global. At initial stage it was touching homo- } \\
\text { sexually oriented people, later it was touching } \\
\text { also heterosexuals. Now there are more than } \\
30 \text { million of people infected with HIV virus, } \\
\text { however there are new medicines that help to } \\
\text { live longer. } \\
21 \% \text { of infected are unaware of that they are } \\
\text { carriers of HIV virus. }\end{array}$ \\
\hline 3 & $\begin{array}{l}\text { Flu Pandemic } \\
\text { (The Hong Kong Flu) }\end{array}$ & 1968 & $\begin{array}{l}1 \text { million (half } \\
\text { of them in } \\
\text { Hong Kong). }\end{array}$ & $\begin{array}{l}\text { Cause: influenza (H3N2 type). It begun in } \\
\text { Hong Kong, but soon was reported in Singa- } \\
\text { pore, Vietnam, Philippines, India, Australia, } \\
\text { Europe and the United States. }\end{array}$ \\
\hline 4 & Asian Flu & $1956-1958$ & 2 million & $\begin{array}{l}\text { Cause: influenza (H2H2 subtype). } \\
\text { It begun in China, then spread across Singa- } \\
\text { pore, Hong Kong and United States. }\end{array}$ \\
\hline 5 & Spanish Flu Pandemic & $1918-1920$ & $20-50$ million & $\begin{array}{l}\text { Cause: influenza. } \\
\text { It begun in France, than spread among many } \\
\text { other countries, including Spain. } \\
\text { This was the global pandemic with } 500 \text { million } \\
\text { people infected. }\end{array}$ \\
\hline 6 & $6^{\text {th }}$ Cholera Pandemic & $1910-1911$ & $\begin{array}{l}\text { More than } \\
800000 \text { in } \\
\text { India alone }\end{array}$ & $\begin{array}{l}\text { Cause: Cholera } \\
\text { It begun in India (as all other Cholera Pan- } \\
\text { demic), then spread across Middle East, North } \\
\text { Africa, North America and Eastern Europe } \\
\text { (with Russia). }\end{array}$ \\
\hline 7 & $\begin{array}{l}\text { Flu Pandemic } \\
\text { (Asiatic Flu or Russian Flu) }\end{array}$ & $1889-1990$ & 1 million & $\begin{array}{l}\text { Cause: Influenza (subtype } \mathrm{H} 2 \mathrm{~N} 2 \text { or } \mathrm{H} 3 \mathrm{~N} 8 \text { ). } \\
\text { It begun in the same time in } 3 \text { separate and dis- } \\
\text { tant locations: in Turkestan, Canada and } \\
\text { Greenland. Then it has become global. The im- } \\
\text { portant factor was rapid growth urban popula- } \\
\text { tion at that time. }\end{array}$ \\
\hline 8 & $3^{\text {rd }}$ Cholera Pandemic & $1852-1860$ & 1 million & $\begin{array}{l}\text { Cause: Cholera. } \\
\text { It begun in India, then spread across the Gan- } \\
\text { ges River Delta, Asia, Europe, North America } \\
\text { and Africa. } \\
\text { During this pandemic (in 1854) British physi- } \\
\text { cian John Snow identified contaminated water } \\
\text { as the means of transmission for the disease. } \\
\text { Earlier they were unknown. }\end{array}$ \\
\hline 9 & The Black Death & 1346-1353 & $\begin{array}{l}75 \text { to } \\
200 \text { million }\end{array}$ & $\begin{array}{l}\text { Cause: Bubonic Plague } \\
\text { It begun in Asia, then spread across Europe, } \\
\text { Africa and Asia. Marine transport was the } \\
\text { means of transmission of the disease, to be ex- } \\
\text { act fleas living on quite common on ships rats. } \\
\text { Ports were at that time urban centres, so the } \\
\text { disease could infect many people quickly. }\end{array}$ \\
\hline 10 & $\begin{array}{l}\text { Antonine Plague } \\
\text { (Plague of Galen) }\end{array}$ & About 165 & 5 million & $\begin{array}{l}\text { Cause: unknown. } \\
\text { The disease was brought to Rome by soldiers } \\
\text { coming back from Mesopotamia. In Europe } \\
\text { countries mostly affected were Italy and } \\
\text { Greece. }\end{array}$ \\
\hline
\end{tabular}

If Covid-19 could cause such mortality (taking into account that the current World population is 7.8 trillion), we would have to face 3.5 trillion deaths!
Epidemics do happen and it is just a matter of time, when we will have the new outbreak.

One of the most important factor is globalization. 
Table 2. Covid-19 in 10 countries with the highest number of infected people as for the May 2020, source: Wikipedia, 2020

\begin{tabular}{|c|c|c|c|}
\hline Country & Infected & Deaths & Recovered \\
\hline USA & 1697361 & 99462 & 352984 \\
\hline Brazil & 376669 & 23522 & 153833 \\
\hline Russia & 362342 & 3807 & 131129 \\
\hline United Kingdom & 261184 & 36914 & No data available \\
\hline Spain & 235400 & 26834 & 150376 \\
\hline Italy & 230158 & 32877 & 141981 \\
\hline Germany & 180808 & 8432 & 120015 \\
\hline Turkey & 157814 & 4369 & 60491 \\
\hline India & 145380 & 4167 & 65199 \\
\hline France & 145279 & 28432 & \\
\hline
\end{tabular}

This phenomena may be defined as an integrated, world-wide social and economic system related to large corporations, characterized by supra-state (and supra-national) diffusion of capital and adoption of the free trade principle in the field of economic globalization and the assimilation of cultural models, especially in the mass form (cultural globalization) (Gawor, 2008).

Globalization is connected with modern transport. Moving around the World has never been easier, than it is today. In case of aviation it is possible to get to the other side of the World in just over a dozen of hours. Unfortunately it applies not only to people or cargo, but also to the diseases.

In last few decades few potentially dangerous accidents did happen (WHO, 2020):

- In 2003 we witnessed SARS (SARS-CoV1) epidemic with 8439 infected, and 812 deaths, mainly in China.

- In 2013 it was Bird Flu (Avian Influenza, Avian Flu, H5N1) epidemic with 861 cases and 455 deaths.

- In 2015 we witnessed Ebola Virus epidemic with 28618 infected and 11310 deaths in Guinea, Liberia and Sierra Leone.

One may say, that we were lucky (especially in case of Bird Flu, where mortality was very high $-53 \%$ ), because none of the above viruses caused global epidemic. In case of Covid-19 the situation is unfortunately different.

\section{Covid-19 - how this could happened?}

As for the $26^{\text {th }}$ May 2020 we have 5.5 million people infected with Covid-19 and more than 346000 deaths (Worldometer, 2020). 10 countries with the highest number or cases are presented in Table 2.

This is the first global pandemic since Spanish Flu Pandemic from the years 1918-1919 (500 million infected and 50 million deaths, MPH, 2020). However in case of Spanish Flu mortality was at the level of $10 \%$, in case of Covid-19 it is less than $1 \%$ and the most important factor is age. As an example, in the UK mortality among children is only $0.0016 \%$, while among people older than 80 years it is $7.8 \%$ (Mahase, 2020). The worst situation, as for the May 2020, was noticed in Norway among people older than 90 years - mortality among them reached $57.1 \%$ (Wikipedia, 2020).

Warnings, that global pandemic is possible, have been reported decades ago.

Joshua Lederberg, molecular biologist and Nobel laureate, once said: The single biggest threat to man's continued dominance on the planet is the virus (Henig, 2020). Even if, as Saleem Ali argues, that only around $1 \%$ of all microbes can actually cause disease in humans (Ali, 2020), it is still quite a lot.

In 2015 r. Bill Gates, founder of the Microsoft Company, warned, that the World is simply not prepared to deal with a disease - an especially virulent flu (...) - that infects large numbers of people very quickly. Of all the things that could kill 10 million people or more, by far the most likely is an epidemic. But I believe we can prevent such a catastrophe by building a global warning and response system for epidemics (Gates, 2015). Unfortunately, we did not build such infrastructure.

The biggest problem in case of spreading Covid-19 pandemic was not the virus itself, but... the politics. The epidemic began in Wuhan, China in the fall of 2019 (Ali, 2020). This is a country with very strong economy, but there is no democratic system, because all power belongs to the Chinese Communist Party. When the first reports from Wuhan appeared, the authorities disregarded the problem and, using their monopoly, forbade the doctors to provide any information outside. It was guarded by the People's Armed Police (as part of the so-called China Information Flow Control Policy). The Chinese admitted the epidemic only when it got out of control (Wasserstrom, 2020). Meanwhile millions of guests, who came to Wuhan to celebrate the new year, had already returned to their countries around the World. The biggest present challenge connected with Covid19 seems to be tracing the infected. Testing as many people as possible is a must, since a lot of people infected - from 25 up to even $80 \%$ - don't have any symptoms of the disease (Healthline, 2020). Such asymptomatic people can infect many others. And we must remember, that although we noticed 346000 deaths caused by the virus, at the same time (between $1^{\text {st }}$ January and the end of May 2020) 25 million people died for natural reasons, cancer, heart 
diseases, in accidents, murdered, or starved to death (Wordometer, 2020).

\section{Covid-19 and environmental engineering}

\subsection{The problematic of environmental engi- neering}

In a Covid-19 pandemic, it seems that technical sciences, such as environmental engineering, are becoming less relevant. However, this is not the truth. According to an interesting definition, adopted by the Environmental Engineering Committee of the Polish Academy of Sciences, environmental engineering is a technical science based on the use of engineering methods (Pawlowski, 2011):

$\checkmark \quad$ For preserving, rationally shaping and using the external natural environment (e.g. water resources, waste management, air protection, soil protection)

$\checkmark \quad$ For preserving and shaping the internal environment of buildings and structures (devices and installations).

In these areas, environmental engineering implements environmentally-friendly initiatives, modifies the technical conditions and technologies to maintain the optimum biological balance of the environment, neutralizes the effects of natural disasters (floods, droughts, or water, air, and soil pollution), and eliminates or reduces the negative environmental impacts of the industrial activities of humans.

What's more, environmental engineering is also very important from the perspective of sustainable development - the central idea of both United Nations, and the EU's legislation.

According to the most widely used definition, sustainable development it is development that meets the needs of the present without compromising the ability of future generations to meet their own needs (WCED, 1987). It includes basic human needs, like access to water, food and shelter, but also to electricity.

Environmental engineering plays an important role in implementing the idea of sustainable development. It shapes the conditions in which a person lives, also refers to the raw material aspect, which in turn determines the satisfaction of material needs both of the present and future generations. It also fulfills many Sustainable Development Goals, introduced by the United Nations in 2015. Among them:

- Goal 6: Clean water and sanitation.

- Goal 7: Affordable and clean energy.

- Goal 8: Decent work and economic growth.

- Goal 9: Industry, innovation and infrastructure.

- Goal 11: Sustainable cities and communities.

- Goal 13: Climate action.

- Goal 14: Life below water.

- Goal 15: Life on land (UN, 2015).
What about being an engineer during Covid-19 epidemic?

\subsection{Internal environment}

In the above definition of environmental engineering it is worth to underline the care about the internal environment. The quality of indoor air and climate have a major impact on our health. And this is especially important during epidemic quarantine, when we are spending much more time at home than usually. Being in a quarantine is also much easier when we have constant access to water or electricity - and these are also engineering issues.

\subsection{Access to water}

In case of water, people in the Western World are lucky, because they live in countries, where this resource generally is available.

From the World's perspective, the lack of access to any water affects about 1 billion people, and another billion has access to water of poor quality (WHO, 2017). Polluted water is the cause of up to $80 \%$ of diseases in developing countries and causes about 3 million victims annually, which is more than in the case of infection with the HIV virus, and of course much more than in case Covid-19. So, still there is great amount of work that should be done.

\subsection{Access to electricity}

The demand for energy is growing everywhere. In 2040 it will double, comparing to the year 2010 (Gore, 2017). Now as much as $87 \%$ of people have access to electricity (UNDP, 2017).

In a quarantine, thanks to electricity, we use the Internet, not only in the aspect of distance learning or entertainment, but also in everyday life. We can easily order any goods that the courier will safely deliver to our apartment.

The problem is however not only how to produce electricity, but also in which way to produce it, since there are different ways, with different environmental consequences.

The worst pollution of the atmosphere is from coal burning power plants, which still are responsible for $38.3 \%$ of the World's gross electricity production (IEA, 2019). The most important polluter is carbon dioxide, which contributes to the global warming, and is responsible for $50 \%$ of the greenhouse effect. The global $\mathrm{CO}_{2}$ emissions in 2017 reached $37,077,404 \mathrm{Mt}$, which was almost twice as much as in 1990 (EPA, 2019). Main polluters are China (10.8 $\mathrm{Gt})$, the USA (4.8 Gt) and the European Union (2.9 Gt). The good news is that in the case of the USA and the EU, the emissions have started to fall down. Unfortunately, this is not the case of China, the impressive industry of this country has its price.

But there are also renewable sources of energy. They are responsible for $26.5 \%$ of the World's gross electricity production (EIA, 2019), and the biggest share in the market is for hydropower (see table 3). 
Table 3. Renewable electricity generation by energy use, source: EIA, 2019

\begin{tabular}{|l|l|c|c|}
\hline No. & $\begin{array}{c}\text { Source } \\
\text { of } \\
\text { energy }\end{array}$ & $\begin{array}{c}\text { Electricity } \\
\text { generated } \\
\text { [TWh] }\end{array}$ & $\begin{array}{c}\text { Share in } \\
\text { the market } \\
{[\%]}\end{array}$ \\
\hline 1 & Hydropower & 4049 & $69 \%$ \\
\hline 2 & Wind & 958 & $16 \%$ \\
\hline 3 & Bioenergy* & 467 & $8 \%$ \\
\hline 5 & Solar & 83 & $6 \%$ \\
\hline
\end{tabular}

*Bioenergy includes solid biofuels, biogas, renewable municipal waste, liquid biofuels

So, renewables even now are a huge part of the energy market, which means they provide jobs for millions of people. According to the UNDP, the renewable energy sector in 2017 gave employment to as many as 10.3 million scientists and workers (IRENA, 2018).

\subsection{Covid-19 and air pollution}

We must be aware, that all the known environmental threats still exist around us, and Covid-19 epidemic should not limit our care for the environment, also on the level of environmental engineering.

It is true, that in case of big cities the quality of air significantly improved, while people were staying at their homes. After introducing lock down in California, the air quality in Los Angeles in early April 2020 become one of the best in the world. Feat impossible to be achieved in normal conditions, with huge car traffic on the streets (IQ Air, 2020). Since the outbreak of the pandemic, Copernicus Sentinel-5P satellite has seen a decrease in air pollution, especially nitrogen dioxide concentrations, across Europe at least by $25 \%$ (Sobuniewska, 2020). The examples from countries heavily touched by Covid-19 pandemic are presented in table 4.

Table 4. Decrease in $\mathrm{NO}_{2}$ concentrations in the air during Covid-19 pandemic in chosen cities of Italy and Spain, source: EEA, 2020

\begin{tabular}{|c|c|c|}
\hline City & Country & $\begin{array}{c}\text { Changes in NO2 } \\
\text { concentration } \\
\text { (March 2020) }\end{array}$ \\
\hline Milan & Italy & $24 \%$ decrease \\
\hline Bergamo & Italy & $47 \%$ decrease \\
\hline Rome & Italy & $30 \%$ decrease \\
\hline Barcelona & Spain & $40 \%$ decrease \\
\hline Madrid & Spain & $56 \%$ decrease \\
\hline
\end{tabular}

Unfortunately this is a temporary effect, so longterm thinking, how to make the situation stable better, is a must.

One of the biggest challenges for the air quality in cities is smog, which is one of the oldest pollution of the atmosphere known. Yet as early as 1542, the Spanish sailor Juan Rodrigez Cabrillo, observed a layer of fog as high as $300 \mathrm{~m}$ around Los Angeles, caused by the smoke from Indian campfires (Wojciechowski, 2006).
Smog is created when the concentration of pollutants (nitrogen oxides, sulphur oxides) in the air is high and when there are specific weather conditions (e.g. no wind, presence of sun, humidity), as well as climatic and topographic conditions hindering the dispersion of pollutants (a valley rather than an open area, Pawłowski, 2011).

Preventing the formation of smog at the industrial level means not only the installation of filters on chimneys, but rather modifications in the production processes (through the implementation of e.g. cleaner production).

Much also depends on us. In the case of so-called London smog, quite common in the World, important source of pollution is the emission from old furnaces in households.

Table 5 presents 10 most polluted cities in the World. None of them lies in Europe or North America. The all represent Asia and the following countries: India, Pakistan and China. Many other cities from these countries are just below the Top 10 .

Table 5. 10 most polluted cities in the World, average results for the year 2019, source: IQ Air, 2020)

\begin{tabular}{|l|l|l|c|}
\hline No. & $\begin{array}{l}\text { Name of the } \\
\text { City }\end{array}$ & $\begin{array}{l}\text { Name of the } \\
\text { country }\end{array}$ & $\begin{array}{c}\text { Average } \\
\text { PM 2,5 }\end{array}$ \\
\hline 1 & Ghaziabad & India & 110.2 \\
\hline 2. & Hotan & China & 110.1 \\
\hline 3. & Gujarnwala & Pakistan & 105.3 \\
\hline 4. & Faisalabad & Pakistan & 104.6 \\
\hline 5. & Delhi & India & 98.6 \\
\hline 6. & Noida & India & 97.7 \\
\hline 7. & Gurugram & India & 93.1 \\
\hline 8. & Raiwind & Pakistan & 92.2 \\
\hline 9. & Greater Noida & India & 91.3 \\
\hline 10. & Bandhwari & India & 90.5 \\
\hline
\end{tabular}

\subsection{Covid-19 and the global warming}

We must also not forget about global threats, like the climate change. One of the consequences of the global warming is connected with tropical cyclones, which are becoming stronger and much more devastating. On $20^{\text {th }}$ May 2020, when the World was still in a quarantine, super cyclone Amphan struck India and Bangladesh. It was the most devastating cyclone in this area ever! Millions of people need help, since whole cities were destroyed, and Covid-19 pandemic is still there (Chowdhuri, 2020).

One of the most important challenges in fighting the global warming is connected with lowering the pollution of the atmosphere with so-called greenhouse gases. The most important such gas is carbon dioxide, but there are others, like: methane, chlorofluorocarbons, ozone and nitrogen oxides (EPA, 2019). Unfortunately the list of GHGs is not closed. In 2013, a new greenhouse gas was found in the atmosphere - perfluorotributylamine (PFTBA), the warming potential of which is 7100 times higher (!!!) than that of $\mathrm{CO}_{2}$ (Science Daily, 2013). This gas is needed for the production of liquids being heat transfer agents in electronic equipment. Unfortunately, no 
action was taken to decrease the emissions of PFTBA to the atmosphere after the discovery, despite the extremely high warming potential.

It cannot be ruled out that man has created many other substances equally dangerous to the climate, only this side of their action has not been recognized yet. This is a very important field of work for scientists and engineers.

\section{Covid-19 and the end of the World as we know it}

One of the most commented books of the 1990s was the work End of History by Francis Fukuyama, published in 1992. The author presented the development of social systems, claiming that liberal democracy is the highest form of political system in history. After the fall of communism, democracy has become the dominant and virtually non-competitive political system in the World, which also means the end of history because other systems will not be formed. The book perfectly fitted into the stream of optimism that prevailed at that time in the World. The fall of communism ended the Cold War era, and humanity would henceforth live in peace.

However, the terrorist attack on New York on September 11, 2001 showed that the time of wars was not over.

What's more, liberal democracy seems to be now in crisis. As prof. Felix Unger, president of the European Academy of Science and Arts, said: when we read the news, when we observe the frustration of people voting the old political parties, when new parties appear without any program, then you feel a new stream of perception of politics is on the way. Most people cannot identify themselves with the political system, which is aggravated by the whole financial crisis. (...) The people in Europe are no longer willing to support banks instead of the people. The main problem is to see that all the political managers have departed from the people and follow only their own interest. The system in Brussels is questionable too. In Brussels they are also far away from the people who, in reality, pay with their taxes everything they are doing. This is deconstruction of our democracy on the way. (...) We all have to serve life not money (...). Life is the highest value and all we have to do is to serve life (Unger, 2013).

Covid-19 pandemic showed, that this life is endangered. It also showed, that political system does matter: China is not a democratic country which, as it was already said, made it easier to hide the threat connected with the virus.

What about democratic countries? Fighting with Covid-19 looks different in different areas. There are two basic strategies:

- First one is to introduce lock-down, closing most business, limiting possibilities for travel and contact for people, which means obligation to stay at home in a quarantine. Most of the countries of the world introduced this solution.

- Second one is to do basically nothing, hoping that the population will get the so-called herd immunity. This strategy was introduced, among others, in the USA, Great Britain and Sweden. However in case of the first two countries this decision provoked protests, as a result, with some delay, lock down was introduced. In case of Sweden there are only suggestions. Swedish Foreign Minister Ann Linde said recently: we advised that everybody should stay at home on Easter and $96 \%$ of people followed it. Our government is acting with suggestions, not prohibitions (Anadolu Agency, 2020).

How will it end? Are we going to face Armageddon? Well, maybe - but for sure not because of the Covid19. The whole biosphere is out of balance, due to business as usual practises, extreme deforestation and pollution of the environment. We must be much more successive in protection of what is left and counteraction major environmental threats, for our own sake. Environmental engineering plays a significant role there.

Covid-19 pandemic will not end the World as such. It will end the World as we know it. First off all the virus already caused gigantic economic crisis, much bigger than the previous crisis from the years 2007 2009 . Some sectors of the economy may cease to exist and the service sector will face a deep recession. This means high unemployment and possible high inflation.

There is a prognosis for the USA (the biggest economy in the World), according to which the unemployment in 2020 is going to be the highest in the history of the country, bigger than during The Great Depression from the 1930 s of the $20^{\text {th }}$ century reaching $32.1 \%$, which means that 46 million (!!!) American citizens will lose their jobs (Roper, 2020) - see figure 1 . In case of weaker economies the problem may be even bigger.

Sectors of the economy, that appeared to be extremely vulnerable in the face of Covid-19 pandemic, are: tourism, public transport, in particular air transport, service sector, cinema and entertainment industry. It showed that the World economy was not so strong, as we thought. After two months of lock down it has been severely damaged.

The worst situation is in tourist sector. For many decades, in many countries, this sector was a primary source of income. Investing in tourism infrastructure (hotels, restaurants, ski resorts) in popular areas was perceived as safe, because for decades it was giving steady income. After just two months of quarantine many of these objects are broken or almost broken. 


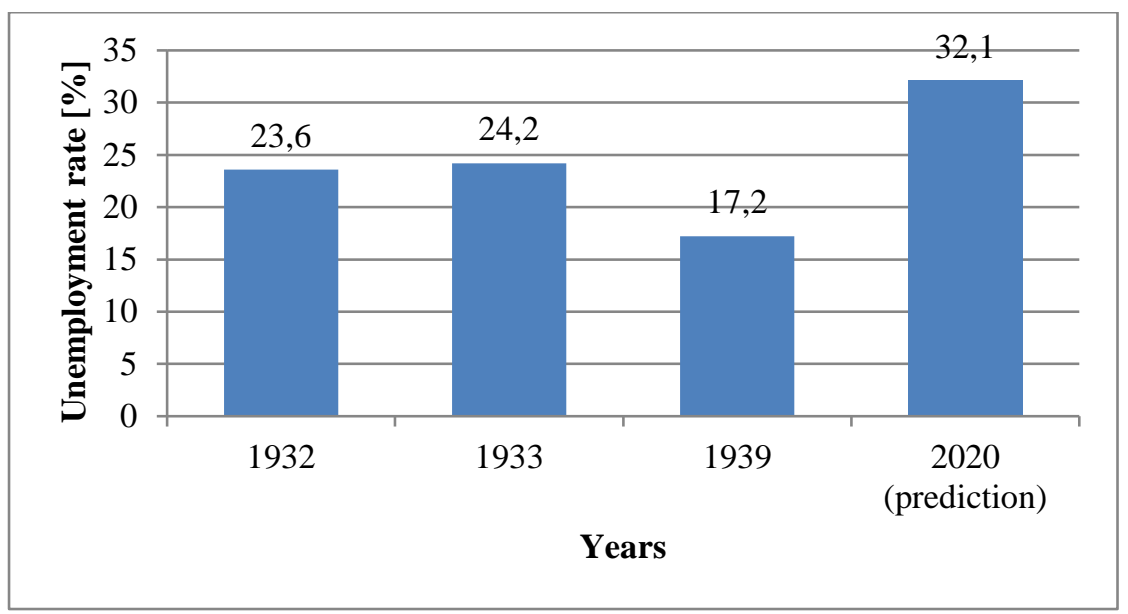

Figure 1. Unemployment in the USA: The Great Depression versus Covid-19, years 1932, 1933, 1939 and 2020, source: Roper, 2020 , changed.

Weakening of our economy means also, that some ambitious goals, like climate and energy policy of the European Union, may be endangered, since problems with financing them are almost certain. As for the end May 2020, because of the Covid-19, we can expect the highest in history plummet in the global energy sector - by $20 \%$ (in comparison to the year 2019, IEA, 2020).

The present horizon of the EU's climate and energy policy is covering the time to the year 2030, and it includes the following goals (EC, 2018):

- Improvement in the energy efficiency, which should be higher by $32.5 \%$.

- Reduction of the greenhouse gases emissions $(40 \%$ by the year 2030 , in relation to the level of emissions from 1990).

- Achieving the level of $32 \%$ of energy production from renewable sources.

Some of the European countries achieved, at least partly, these goals already. For example, in Norway almost all electricity is produced by hydropower stations (Salay, 1997), but for many other countries it is going to be a real challenge, mainly because of the economic crisis, which has already begun.

Also industry suffers from Covid-19 pandemic. As we know, the second biggest economy of the World is China. In the first quarter of 2020, China's GDP went down by $6.8 \%$. This was the first decrease from 1992 (Nagarajan, 2020)!

All of this means a gigantic economic crisis and retraction of the World development many years back. Governments are aware of the crises and are trying to help the economy by loosening the restrictions connected with lock down. Let's hope that it will not increase significantly the number of infected, because in such case another full lock down could be a must.

\section{Conclusions}

Many people thought that global pandemic, as known from the past, in our modern World is not possible. Unfortunately they were wrong. Fighting with Covid-19 we cannot however forget, that there are many other problems, which are also responsible for the death of a lot of people.

Our planet is ecologically out of balance, and global threats, such as global warming, may take much more lives, than Covid-19. Although environmental engineers cannot create vaccine for the virus (it is the duty of medical sciences), they are still needed, since state of the environment is also crucial to our health, and they have the right technologies for protection of the environment.

Underlined in the title of this paper phrase: the end of the world as we know it relates to the economy. Most of us will survive Covid-19, but we may lose our jobs, and the global economy is going to be in a very deep crisis, much deeper than even the tragic Great Depression from the 1930s. We are in the middle of the pandemic now, and future is unpredictable, however it can be assumed, that economic recovery will take much more time, than the epidemic itself. But there is another important factor, which can change the situation. Covid-19, as any virus, mutates randomly. One of the next mutations can make it harmless. One of the next mutations can make it more dangerous. Let's hope that the first option will happen.

\section{References}

All Internet articles were retrieved in May 2020.

1. AGARAJAN S., 2020, China's economy suffers its first contraction in 28 years, shrinking $6.8 \%$ in an 'extraordinary shock' to the global economy, in: Business Insider.com, https://www.businessinsider.com/ china-economy-falls-first-quarter-2020-after-half-ce ntury-growth-2020-4?IR=T.

2. ALI S., How the current coronavirus pandemic links to questions of ecological sustainability in the Anthropocene?, in: Springer Nature Sustainability Community, https://sustainabilitycommunity.springernatu re.com/users/183121-saleem-ali/posts/63681-how-th e-current-pandemic-links-to-broader-questions-of-su stainability-in-the-anthropocene. 
3. ANDOLU Agency, 2020, Has Sweden's different COVID-19 response paid off?, https://www.aa.com.tr /en/europe/has-swedens-different-covid-19-response -paid-off/185 7605.

4. CHOWDHURI R. De, 2020, Cyclone Amphan hits India and Bangladesh, https://edition.cnn.com/2020/ 05/20/weather/gallery/cyclone-amphan/index.html.

5. EEA, 2020, Air pollution goes down as Europe takes hard measures to combat coronavirus, https://www. eea.europa.eu/highlights/air-pollution-goes-down-as.

6. EIA, 2019, Electricity information. Statistics, https:// iea.blob.core.windows.net/assets/722cdfb8-a938-43 d6-ad99-1fbf3e53bf8e/Electricity_Information_2019 Overview.pdf.

7. EC (European Comission), 2018, 2030 climate \& energy framework, Brussels.

8. FUKUYAMA F., 1992, The end of history and the last man, Free Press, New York.

9. GATES B., 2015, Gates Notes, We're not ready for the next epidemic, https://www.gatesnotes.com/ Health/We-Are-Not-Ready-for-the-Next-Epidemic.

10. GAWOR L., 2008, Globalization and its Alternatives: Antiglobalism, Alterglobalism, and the Idea of Sustainable Development, in: Sustainable Development, 16(2), p. 126-134.

11. GORE A., 2017, An Inconvenient Sequel, Rodale Books, Emmaus.

12. Healthline, 2020, As Many as 80 Percent of People with COVID-19 Aren't Aware They Have the Virus, https://www.healthline.com/health-news/50-percentof-people-with-covid19-not-aware-have-virus.

13. HENIG R.M., 2020, Experts warned of a pandemic decades ago. Why weren't we ready?, in: National Geographic, https://www.nationalgeographic.com/ science/2020/04/experts-warned-pandemic-decadesago-why-not-ready-for-coronavirus/.

14. IEA, 2020, The largest decline in global energy investment in history, https://www.iea-coal.org/thelargest-decline-in-global-energy-investment-in-histo ry/ (1.06.2020).

15. IRENA, 2018, Renewable Energy Jobs Reach 10.3 Million Worldwide in 2017, Press Release, https://www.irena.org/newsroom/pressreleases/2018 /May/Renewable-Energy-Jobs-Reach-10-MillionWorldwide-in-2017.

16. IQ AIR, 2020, Report: Covid-19 Impact On Air Quality In 10 Major Cities, https://www.iqair.com/blog/ air-quality/report-impact-of-covid-19-on-global-airquality-earth-day.

17. IG AIR, 2020, World's most polluted cities 2019 (PM 2.5 ), https://www.iqair.com/world-most-polluted-cities?page $=1 \&$ perPage $=50 \&$ cities $=$

18. MAHASE E., 2020, Covid-19: death rate is 0.66\% and increases with age, study estimates, https://www. bmj.com/content/369/bmj.m1327.

19. MPH on line, 2020, Outbreak: 10 of the Worst Pandemics in History, https://www.mphonline.org/worst -pandemics-in-history/.

20. PAWŁOWSKI A., 2011, Sustainable Development as a Civilizational Revolution. Multidimensional Approach to the Challenges of the $21^{\text {st }}$ Century, Taylor
\& Francis Group, CRC Press, Boca Raton, London, New York, Leiden.

21. ROPER W., 2020, Predicted Unemployment Higher Than Great Depression, https://www.statista.com/ chart/21329/highest-unemployment-rates-ever/.

22. SALAY J., 1997, Energy, from fossil fuels to sustainable energy resources, Baltic University Press, Uppsala.

23. SOBUNIEWSKA M., 2020, Czy koronawirus jest dobry dla środowiska?, Klub Jagielloński, https://klubjagiellonski.pl/2020/05/22/czy-koronawirus-jest-dobry-dla-srodowiska/.

24. UN, 2015, Sustainable Development Goals, https://sustainabledevelopment.un.org/?menu=1300.

25. SCIENCE Daily, 2013, New long-lived greenhouse gas discovered: Highest global-warming impact of any compound to date, https://www.sciencedaily.com /releases/2013/12/131209124101.htm.

26. UNDP, 2017, Sustainable Development Goals: Goal 7: Affordable and clean energy, https://www.undp. org/content/undp/en/home/sustainable-developmentgoals.goal-7-affordable-and-clean-energy.html.

27. UNGER F., 2013, Address to the Members of European Academy of Science and Arts, European Academy of Science and Arts, Salzburg.

28. WASSERSTROM J., 2020, China's response to coronavirus exposes a dangerous obsession with secrecy, in: The Guardian, 5 Febuary, https://www. theguardian.com/commentisfree/2020/feb/05/chinaresponse-coronavirus-obsession-secrecy.

29. WCED (World Commission on Environment and Development), 1987, Our Common Future, Oxford University Press, New York.

30. WHO, 2020, Cumulative number of confirmed human cases of avian influenza A(H5N1) reported to WHO, https://www.who.int/influenza/human_animal _interface/H5N1_cumulative_table_archives/en/.

31. WHO, 2020, Cumulative Number of Reported Probable Cases of SARS, https://www.who.int/csr/sars/ country/2003_07_04/en/.

32. WHO, 2020, Hiv/Aids, https://www.who.int/gho/hiv /en/.

33. WHO, 2020, Ebola virus disease, https://www.who. $\mathrm{int} /$ news-room/fact-sheets/detail/ebola-virus-disease.

34. WHO, 2017, 2.1 billion people lack safe drinking water at home, more than twice as many lack safe sanitation, https://www.who.int/news-room/detail/12-072017-2-1-billion-people-lack-safe-drinking-water-athome-more-than-twice-as-many-lack-safe-sanitation

35. WIKIPEDIA, 2020, Template: COVID-19 pandemic data, https://en.wikipedia.org/wiki/Template:COVI D-19_pandemic_data.

36. WOJCIECHOWSKI K.H., 2006, Niemierzalne składniki krajobrazu, in: Wspótczesne problemy ochrony krajobrazu, ed. Kucharczyk M., ZLPK, Lublin, p. 17-23.

37. WORLDOMETER, 2020, Current World Population, https://www.worldometers.info/world-populati on/.

38. WORLDOMETER, 2020, Coronavirus Cases, https: //www.worldometers.info/coronavirus/. 